\title{
Article \\ Social License to Operate in Geothermal Energy
}

\author{
Amel Barich ${ }^{1, *(\mathbb{D}}$, Alicja W. Stokłosa ${ }^{1}$, Jan Hildebrand ${ }^{2}$, Ottó Elíasson ${ }^{3}$, Tamás Medgyes ${ }^{4}{ }^{\mathbb{D}}$, Gauthier Quinonez ${ }^{5}$, \\ Ana C. Casillas ${ }^{6}$ and Isabel Fernandez ${ }^{7}$
}

1 Geothermal Research Cluster (GEORG), Bjargargata 1, 102 Reykjavik, Iceland; aws@georg.cluster.is

2 Institute for Future Energy and Material Flow Systems (IZES), Altenkesseler Straße 17, Geb. A1/B4, 66115 Saarbrücken, Germany; hildebrand@izes.de

3 Eimur, Hafnarstræti 91, 600 Akureyri, Iceland; ottoel@eimur.is

4 District Heating Company of Szeged (SZETAV), Vág u. 4, 6724 Szeged, Hungary; tmedgyes@yahoo.com

5 La Palma Research Centre, Rue Vautier 54, 1050 Brussels, Belgium; gauthier.quinonez@lapalmacentre.eu

6 Spanish Geothermal Technology Platform (GEOPLAT), c/Doctor Castelo 10, 4 D, 28009 Madrid, Spain; acasill1@tragsa.es

7 European Federation of Geologists (EFG), Rue Jenner 13, 1000 Brussels, Belgium; isabel.fernandez@eurogeologists.eu

* Correspondence: amel@georg.cluster.is

Citation: Barich, A.; Stokłosa, A.W.; Hildebrand, J.; Elíasson, O.; Medgyes, T.; Quinonez, G.; Casillas, A.C.; Fernandez, I. Social License to Operate in Geothermal Energy. Energies 2022, 15, 139. https:// doi.org/10.3390/en15010139

Academic Editor: Gianpiero

Colangelo

Received: 6 November 2021

Accepted: 21 December 2021

Published: 26 December 2021

Publisher's Note: MDPI stays neutral with regard to jurisdictional claims in published maps and institutional affiliations.

Copyright: (C) 2021 by the authors. Licensee MDPI, Basel, Switzerland. This article is an open access article distributed under the terms and conditions of the Creative Commons Attribution (CC BY) license (https:// creativecommons.org/licenses/by/ $4.0 /)$.

\begin{abstract}
Geothermal energy is a resource that has the potential for development in many countries around the world. Despite its versatility and economic viability, this resource faces numerous obstacles that hinder its deployment and capacity for achieving a similar market share as other renewable and clean energy sources. Both technical and non-technical barriers can be highly detrimental to the implementation of geothermal projects. A social license to operate (SLO) is a tool that can help the deployment of geothermal energy. As a new concept, SLO is little developed in the business literature but is still being adopted in many industries. Its main challenges reside in its contextdependence and the lack of clear frameworks to utilize it. This paper introduces, in a first known attempt, through a qualitative approach, a conceptual model of the social license to operate in the geothermal energy sector. For its development, three case studies, working group discussion and surveying were conducted in the framework of the H2020 funded CROWDTHERMAL project, which aims to empower EU citizens for direct participation in geothermal projects through crowdfunding. Findings of this paper also drew on existing general conceptual models of the SLO, and experiences from other sectors that have developed their own SLO models. The paper contributes to a more contextualized understanding of the social license within the geothermal sector and sheds the light on practices and challenges that influence the acquisition and maintenance of SLO in geothermal energy projects and initiatives.
\end{abstract}

Keywords: social license; SLO; geothermal energy; CROWDTHERMAL project

\section{Introduction}

With the increasing need to achieve the energy transition and mitigate climate change, renewable energies have become a necessary alternative to conventional energy sources, such as fossil fuels. While certain forms of renewable energy like solar and wind have become increasingly popular, geothermal lags behind and faces a slow development, despite its ubiquity and efficiency.

Geothermal energy is heat generated within deep Earth and stored throughout its crust. This natural clean indigenous resource is available all around the globe, and its concentration is highly dependent on the general geological context (greater concentrations in hydrothermal systems in volcanic regions, at plate boundaries, lower concentrations in thermal gradient in shallow levels). Geothermal resources can, thus, be harnessed either for electricity production or directly used for heating, cooling, and hot water [1,2].

Compared to other alternative and renewable energies, one strength and uniqueness of geothermal energy resides in its stability, power, low to no gas emissions, and the large 
spectrum of its applications, regardless of meteorological conditions [3,4]. According to the Technology Roadmap for Geothermal Heat and Power, issued by the International Energy Agency, geothermal energy could contribute by 2050 to about $3.5 \%$ of global electricity production ( $1400 \mathrm{TWh}$ per year), avoiding a yearly $\sim 800 \mathrm{Mt}$ of $\mathrm{CO}_{2}$ emissions [5]. Moreover, geothermal energy proved to be a team player in the renewable energy mix, with its capacity to provide and integrate hybrid configurations and, therefore, increase energy security and efficiency $[1,6,7]$. However, despite its reliability and ubiquity, similar to other resources, this alternative energy faces its own particular challenges, limiting its deployment. These challenges include fundamental technical barriers, such as geological certainty and accessibility, the high cost of development, and potential environmental effects linked to practices such as induced seismicity, land changes, noise and sight pollution, gas emissions, and soil subsidence [8-15].

Although technical barriers may hinder, to an extent, the implementation of geothermal projects (and this has given incentive to many initiatives to engineer new solutions and mitigate environmental impacts $[15,16])$, the social barriers and perception of geothermal energy remain a critical obstacle to its deployment, limiting its chances of financing and securing support at different governance levels. This issue is not exclusive to geothermal energy; in the context of the global energy transition and efforts to tackle greenhouse emissions, approval of the implementation of renewable energies by the public is as important as their technological reliability [17-20]. Despite the large acceptance of renewable energies as a concept, examples from various countries showed that public resistance can be detrimental to the implementation of renewable energy technologies (RET) and infrastructure [20-24]. This resistance was connected by social scientists, mainly to the lack of understanding at the local level of renewable energy [25], which translates often into opposition (manifesting among other things through the NIMBY (not in my back yard) syndrome [26,27], a concept deemed too simplistic and not reflecting the complexity of the different elements and factors leading to this resistance [28]). Among the other renewable and clean energies, geothermal is yet one of the least understood by non-expert communities; therefore, more subject to skepticism from communities. Given its nature as a resource that is harnessed from the subsurface, its perception from the public can easily be negative, especially in the absence or lack of communication and awareness campaigns, incoherence with local policies, and an unmatching purpose of the project [29]. Failing to socially engage with the community and initiate a good quality dialogue upstream can quickly become detrimental for the future of a geothermal project. In the light of these non-technical barriers preventing deployment of this resource, and in the dawn of the geothermal decade [30,31], aiming to reposition geothermal energy as a major player in the energy transition, an increasing number of geothermal developers are realizing the importance of gaining social support and maintaining it order to ensure the successful deployment of this resource and achieve its legitimacy as a viable clean alternative solution in the new energy era we are currently transitioning to. The process of building and maintaining this social support is part of the 'Social License to Operate' (SLO) construct [32]. Given that SLO is relatively a new paradigm and that the geothermal industry is still emerging, the lack of experience and clear model, as well limited literature on the subject, contribute to maintaining this challenge and, consequently, slowing down the overall progress of geothermal energy deployment. Although SLO is a term mentioned across the industry [33], its understanding is still abstract in the absence of a guiding framework.

Through this paper, we are seeking to explore the concept of the SLO, its potential role in supporting geothermal energy deployment, and propose-in a first known attempt, a conceptual model of the SLO in geothermal energy. This study is based on qualitative research, performed within the CROWDTHERMAL [34] project framework, through surveying and working group discussions, involving different actors from the geothermal field (geothermal developers, NGOs, and scientists).

This paper will begin by exploring the definition and general theoretical frameworks of the SLO, through a comprehensive literature review. It is followed by an outline of 
the methodological approach followed in this research. The Section 4 explores at first the definition of SLO in geothermal energy, then the conceptualization process of SLO is presented, where we identify the stakeholders and their concerns (two key elements in addressing SLO in terms of challenges and practices), including an analysis of the case studies of this research. The second part of Section 4 will finally present the conceptual framework of SLO in geothermal energy and associated mitigation strategies to address stakeholders' expectations.

\section{Social License to Operate (SLO): A Literature Review}

A social license to operate (SLO) is a multiscale, multilevel, intangible agreement that represents an implied consent from affected stakeholders towards projects developed by businesses or industries, independent from legal or statutory requirements [35]. This theoretical construct emerged in the late 1990s in the mining industry [36] and has since become ubiquitous in natural resources industries. Beyond the extensive research focus on the application of this concept in the extractive industries, SLO is also used to an increasing extent in other sectors, such as forestry, agriculture, blue economy, renewable energy, and pulp and paper manufacturing [32,37-44]. An ethical concept, the SLO term was deployed by the United Nations (UN) Guiding Principles on Business and Human Rights (UNGPs) and the UN 'Protect, Respect and Remedy' Framework and was utilized as grounds for responsible business conduct and a tool to broaden the concept of corporate social responsibility (CSR) [45].

\subsection{The Nature of SLO}

Some studies classify SLO in two categories: instrumental and critical [38]. The instrumental aspect of the SLO relates to its structure and components, particularly on ways businesses or industries might achieve and maintain social and political trust and legitimacy [38]. Indeed, although legal contracts for business operations are mandatory for any development operations, those regulatory approvals do not necessarily equate to social approval of the same activity [32]. A legal license is issued by a legal authority, while a social license is perceived as something that must be earned from the community [46]. Besides, SLO is also a highly dynamic, changeable, and context-dependent concept [32]. It is an ongoing process that runs through the entire lifecycle of a project [39] and varies in construct and strength from one industry to the other [32].

SLO draws from concepts of corporate social responsibility [47] and has linkages with concepts, such as sustainability and sustainable development [32]. In current diversified and novel socioeconomic and environmental contexts, SLO has become an important part of the discourse on resources extraction among academics, community engagement practitioners, and industry executives, and the need to attain an SLO ranked in the past few years as third on a list of the top ten industry challenges $[48,49]$. The SLO is also an ethical construct, hence its critical nature. The social capital built around the SLO fosters the ethical behavior of businesses. Indeed, businesses building community with various stakeholders' groups, even when a shared vision is not possible, is what makes those stakeholder groups partners in solving problems, rather than protestors, and makes, therefore, this consultative process of ex-changing expectations, signaling priorities, and seeking amenable solutions of material importance $[50,51]$.

\subsubsection{A Multilevel and Multiscale Construct}

SLO is not restricted to local operations only, it also applies to multiple scales and levels. Indeed, SLO can be examined within regional and national contexts, as well as at the international level, in order to determine not only whether single operations hold a social license with their community but also whether entire industries have earned their social licenses from the broader public [32,52]. 


\subsubsection{SLO-A Trust and Legitimacy Tandem}

The need for an SLO implies a growing pressure on businesses and industries to seek and gain acceptance from stakeholders. According to some studies, decrease of public trust in governmental institutions and the legitimacy of some environmental regulations are correlated to the SLO necessity $[38,39,53,54]$.

Indeed, strong public opposition can affect the success of a project, and the withdrawal of an SLO can put an immediate halt to a development activity or project.

\subsubsection{A Measurable Concept}

Part of the conceptualization of an SLO includes indicators that help measure its levels. These social metrics are connected to social engagement activities, aiming at enhancing public knowledge, through communicating technical complex information to non-technical stakeholders. Indicators vary, according to the social license framework, e.g., economic legitimacy, socio-political legitimacy, institutional trust, and interactional trust are SLO indicators. SLO is ideally measured at the beginning of the project, during the business case phase, to establish a baseline, and then research is repeated periodically through the other phases of the project. On the other hand, studies emphasized that SLO may vary in their strength [55]. This variation reflects the different levels of social approval and acceptance $[47,56]$. The distinction between approval and acceptance reflects the "two levels of the SLO: the lower level being acceptance and the higher-level approval" [47].

\subsection{How Is SLO Used and Acquired?}

Since SLO is a relatively recent theoretical construct, a relatively small quantity of systemic literature reviews has been dedicated to understanding its conceptual evolution and implication for management practices [57].

Context-dependent by nature, SLO is usually obtained on a project or community specific basis, as each situation and community are different.

The social license, in the context of a natural resource project, requires trust. As trust legitimates-in a social license-decision processes, it is also the basis for and result of good governance. Building trust and credibility with stakeholders requires continuous, effective, and timely communication activities, as well as meaningful dialogue and ethical and responsible environmental and social behavior [58].

Efforts to gain SLO start prior to the implementation of the project. Conducting social studies is a first step for organizations to understand the social structure and be aware of the concerns and perceptions of stakeholders.

Asmus [59] identifies three key issues that must be resolved when constructing an SLO:

1. How is "the community" defined? Is there a strict geographical limitation to "community", and are elected officials given greater or equal status to local citizens?

2. If there is a lack of consensus within the "community," what process validates any decision-making (i.e., a majority vote of the local governing body; a referendum)?

3. Third item. Absent a political process, what exactly represents an adequate level of consent?

\subsection{SLO Theoretical Frameworks}

SLO can be developed through three frameworks, identified by Gehman et al. [60], in an attempt to structure the SLO process, these structures are the: pyramid, triangle, and three-strand models (Figure 1). 


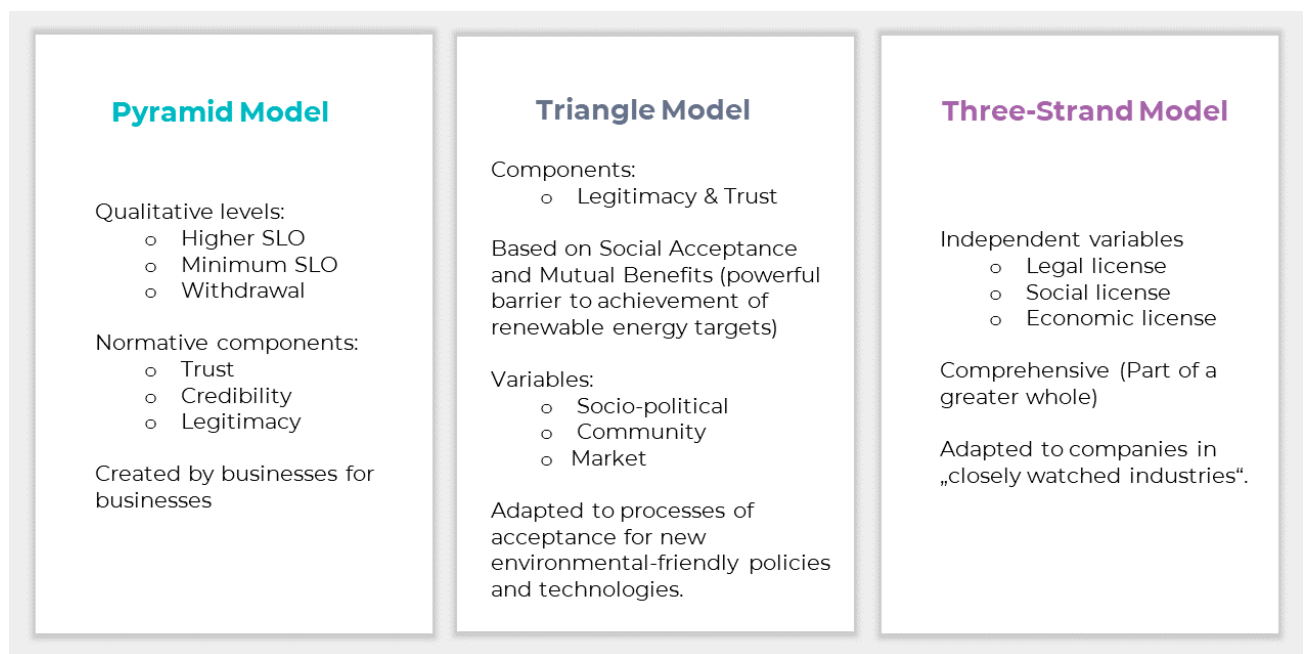

Figure 1. Structuring the SLO process: pyramid, triangle, and three-strand model characteristics.

The most adopted model in SLO is the pyramid model. It was developed by Boutilier and Thomson [61]. This model is based on qualitative levels of SLO separated by boundaries ranging from withheld or withdrawn social license as minimum level to higher-level social license. The pyramid model (Figure 2) focuses on normative components such as legitimacy, credibility, and trust [62,63].

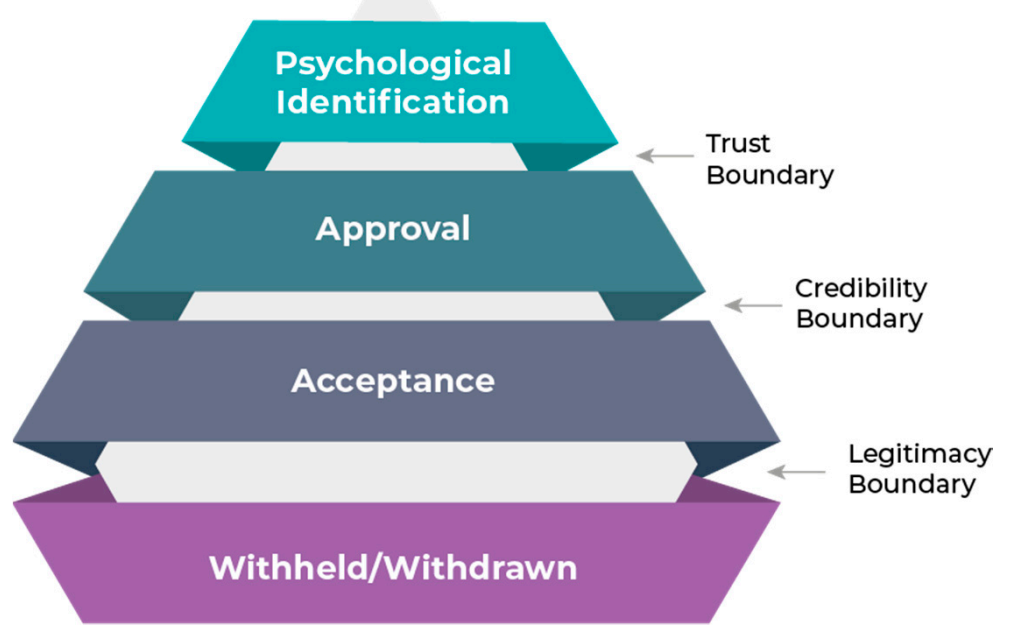

Figure 2. SLO pyramid model (modified after Thomson and Boutilier, [47]).

Thomson and Boutilier [47] claimed that the level of SLO granted to a company is inversely related to the level of socio-political risk a company faces. A lower SLO indicates a higher risk. The highest level of SLO is "psychological ownership"; this level requires passing a threshold of "full trust", where the dissolution of the "us-them boundary" occurs, the company becomes an insider in the community social network, and members of the community actively defend the company or project against outside criticisms [64]. In this model, Thomson and Boutilier [47] also distinguished between SLO acceptance and SLO approval, where SLO acceptance refers merely to stakeholders' tolerance towards the project/company activities whereas SLO approval refers to support from stakeholders. 
The triangle model (Figure 3) is rooted in the concept of "social acceptance" [60]. The term social acceptance is perceived as "building confidence, familiarity, and trust in environmentally-friendly but unproven technologies". Social acceptance is also described as "a powerful barrier to the achievement of renewable energy targets" [65]. Moreover, factors such as trust, perceived impacts, governance, legitimacy, and fairness, among others were found as a base for social acceptance [48,66-69].

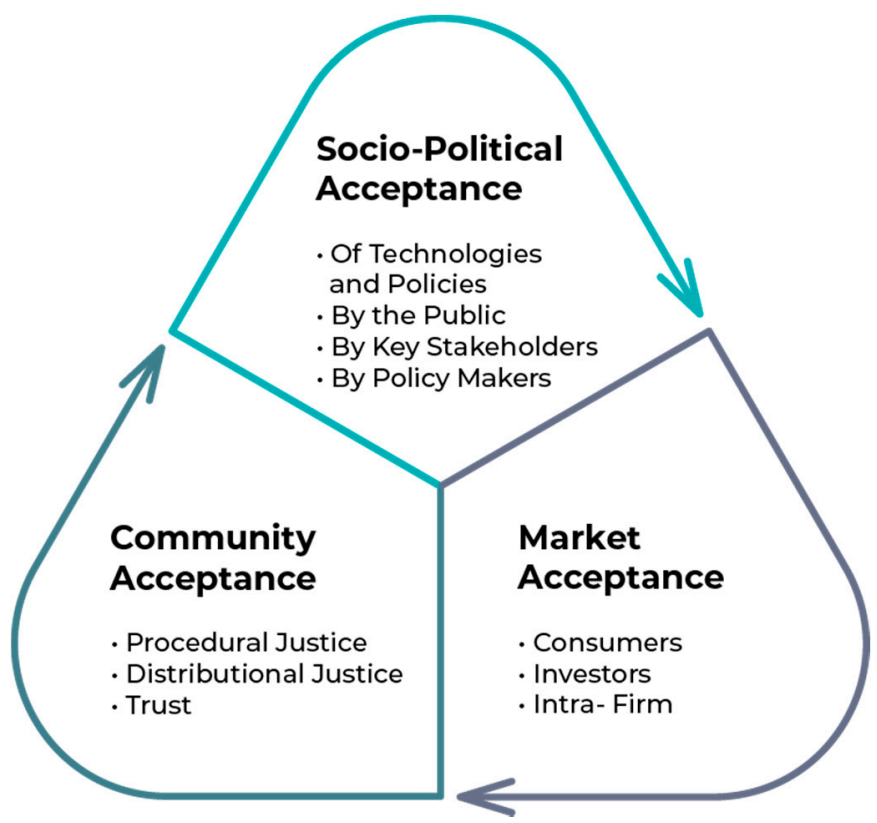

Figure 3. The triangle model (modified after Wüstenhagen et al. [65]).

Three dimensions of social acceptance are identified in the triangle model [65]:

- Socio-political acceptance: general social acceptance of policies and technologies by the public, key stakeholders, media, and policymakers.

- Community acceptance: acceptance of specific projects and locations by local stakeholders such as residents and local authorities.

- Market acceptance: wider market response to an innovation (involved actors are consumers, investors, and producers).

The three-strand model is the third variety of the SLO (Figure 4). It stemmed from a series of interrelated works in 2003 and 2004 [36,70-72], on the basis of exploring the research question on why corporate environmental performance has improved over time and how corporations can be motivated to go beyond compliance with existing environmental regulations. The results of the studies suggest that the concept of SLO is an extension of legal and economic licenses, and companies who belong, particularly, to "closely watched industries" depend, therefore, on a multistranded license to operate.

The three-strand model [57] includes therefore three independent variables linked to:

- the legal license aspect, which pertains to the current legislation;

- the economic license aspect, granted by the market and investors;

- the social license aspect, granted by a range of stakeholders who albeit unofficially, enforce compliance. 


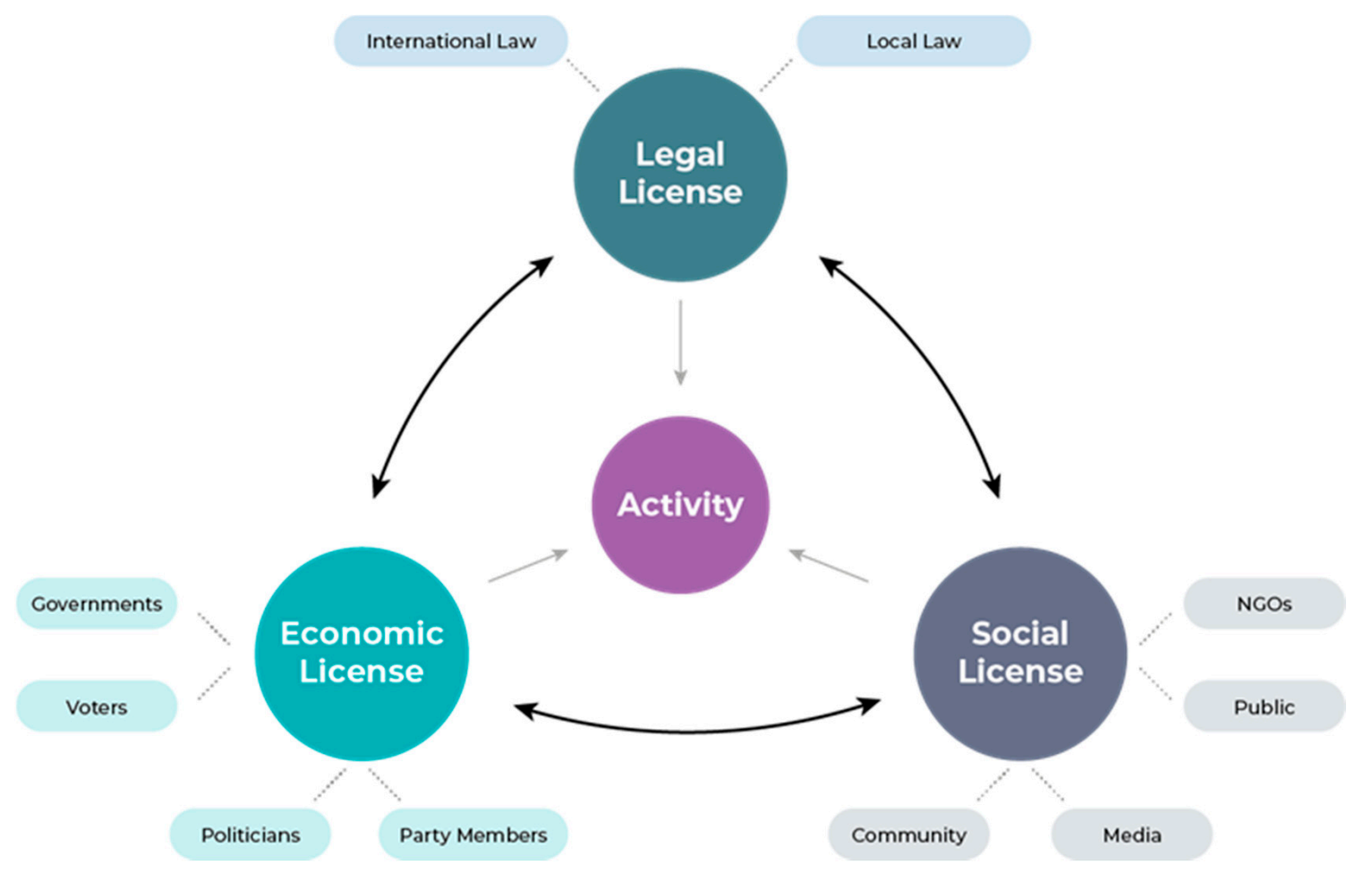

Figure 4. The three-strand model (modified after Morrison, [73]).

\subsubsection{Social Acceptance and Social License to Operate}

Although intrinsically connected, it is important to differentiate between the concept of social acceptance and a social license to operate. They should not be equated as they are of two different natures. The first is a common and elementary feature of the SLO, whilst the second is a tool and much broader concept, with much deeper political ties [74].

\subsubsection{Building and Maintaining the SLO}

SLO is deeply dependent on building trust between communities and businesses, and, once achieved, it must be carefully maintained. The timing of the acquisition of an SLO is also crucial. A well-established SLO is one that is coupled with consistency and nurturing, leading to building legitimacy, credibility, and trust with the stakeholders, and ultimately reaching not only acceptance but also approval and support [58].

\section{Methods}

A qualitative thematic analysis has been used to systematically identify and organize the patterns within the data extracted by literature analysis and structured group discussions [75]. By this means, this research includes the existing conceptual frameworks of social SLO approaches to explore the similarities and differences. Therefore, the categorization procedure combined both the descriptive and interpretative approach to identify the data. Thematic analysis approach contains six main steps; getting familiar with the data, generating initial codes, searching for themes, reviewing potential themes, defining and naming themes, and, finally, producing the report [75].

The analytical framework draws on the SLO-related theories, such as acceptance and involvement. Moreover, reflections from the literature review and group discussions shaped the further development of analysis structure. The developed framework recognizes that investigating SLO requires three categories; definitions/models, influencing factors and impacts, which can be seen in Table 1. 
Table 1. Analytical framework of SLO.

\begin{tabular}{|c|c|c|}
\hline \multirow{5}{*}{ 1. Definitions } & \multirow{2}{*}{ 1.1. Function } & 1.1.1. Organizational philosophy \\
\hline & & 1.1.2. Tool \\
\hline & \multirow{3}{*}{ 1.2. Structure } & 1.2.1. Pyramid \\
\hline & & 1.2.2. Triangle \\
\hline & & 1.2.3. Three-strand \\
\hline \multirow{5}{*}{ 2. Influencing factors } & \multirow{3}{*}{ 2.1. Public involvement } & 2.1.1. Dialogue \\
\hline & & 2.1.2. Trust \\
\hline & & 2.1.3. Co-production \\
\hline & \multirow{2}{*}{ 2.2. Mutual benefits } & 2.2.1. Benefit sharing \\
\hline & & 2.2.2. Cost-Benefit balancing \\
\hline 3. Impacts & 3.1. Positive local relation & $\begin{array}{l}\text { 3.1.1. Psychological identification } \\
\text { 3.1.2. Approval } \\
\text { 3.1.3. Acceptance } \\
\text { 3.1.4. Social Capital }\end{array}$ \\
\hline
\end{tabular}

\section{Results}

\subsection{Social License to Operate for Geothermal Energy}

The SLO concept originated from the mining sector in 1997 and quickly became part of the jargon used, when discussing social aspects of mining projects [47]. With the rising of criticism and opposition to mining projects, SLO became a tool to gain back legitimacy to proceed with mining projects [55,76,77].

Most of the literature to-date on SLO is dominated by research related to the extractive industries; however, this paradigm is being increasingly investigated and applied in other sectors, including renewable energy industries [32,37].

Hall et al., [32] explored SLO across energy industries in an attempt to understand its application in different energy sectors. Perceptions covered were of the sectors of mining, wind, Carbon Capture and Storage (CCS), and geothermal. In a comparative perspective (Figure 4), it is noticed that geothermal energy shares perceptions with all the afore-mentioned industries, these perceptions include the permission/approval, land use, and mutual benefits, as well as the acceptance of the industry as a whole. Perceptions around geothermal also include the environmental risks (including induced seismicity) and concerns about resources use, such as water (Figure 5).
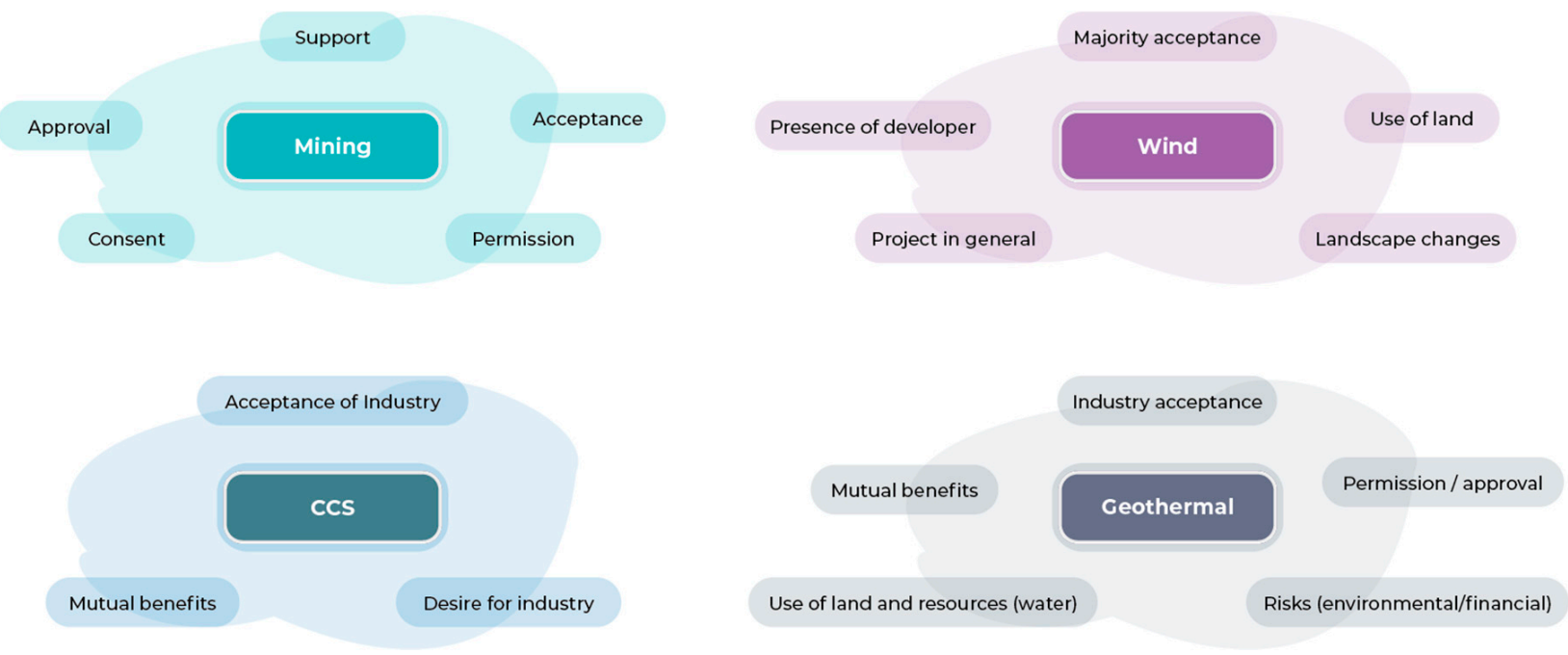

Figure 5. SLO perception around natural resources industries (based on Hall et al., [32]). 


\subsection{Conceptualizing SLO in Geothermal Energy-A CROWDTHERMAL Study}

CROWDTHERMAL is a Horizon 2020 funded project, of which the central objective is to empower the European public to directly participate in the development of geothermal projects, with the help of alternative financing schemes (crowdfunding) and social engagement tools [34]. The CROWDTHERMAL consortium includes ten parties, with the aim to shed light on social aspects, financial alternatives, and risk mitigation strategies for geothermal projects development. Within the project, there are three case studies and several working groups operated, and one of them addresses the topic of the SLO. The working group includes seven members from different geothermal sectors (private, NGOs, research).

CROWDTHERMAL case studies involved in this work are aimed to provide an indepth understanding of the conceptualization of SLO. They are located in Spain, Hungary, and Iceland. The selection of those three case studies was determined according to their geothermal context and utilization, the range of the development stages, and cultural values and perceptions of geothermal energy.

In the following section of this article, we explore the different constituents of the SLO conceptual framework. Based on case studies, SLO working group discussions, and prior stakeholders' analysis in the framework of the CROWDTHERMAL project [78], we identify (1) groups of stakeholders who influence SLO, (2) their issues and concern, (3) value creation, and (4) classification of issues (tangible and intangible).

\subsubsection{Stakeholders Identification}

The focus on stakeholder and community support for geothermal (and other industrial) projects requires answering the following question-who "grants" the social license? Identifying which stakeholders might influence SLO is a key challenge. In general, the stakeholders identified to be most likely relevant to questions of SLO in the geothermal sector fall into two main categories. There is a core stakeholders' group usually geographically connected to the project, and another group broadly and indirectly connected to it.

From the CROWDTHERMAL stakeholder's analysis [78], the stakeholders identified through the case studies go under the following roles: initiators of the project, operators, constructors, direct and indirect users, local authorities (municipalities, districts, regions, provinces, and city \& county councils, and other government tiers), financial investors (e.g., private, EU funds), scientific communities (universities, research centers, geological surveys), non-profits organizations (advocates for clean energy, environmental associations, etc.), residents, multiplicators (media, tourism sector, word-to-mouth), and facilitators.

As SLO is a multiscale construct, geothermal stakeholders also occur at a broader scale.

Stakeholders differ from one place to the other and from one project to the other. However, Geothermal ERANET stakeholder analysis in 2013 identified geothermal stakeholders at national level in several participating European countries. The broader stakeholders group include:

- Government institutions,

- Academic institutions,

- Power industry (important in some countries, where high-enthalpy resources are already exploited or where a high potential is expected),

- Industry, private companies,

- Public,

- Non-governmental organizations (NGOs).

\subsubsection{Stakeholders' Issues and Concerns}

Addressing stakeholders' issues and concerns is a crucial part in the process of establishing a successful SLO. It is important to acknowledge the potential of geothermal to have both negative and positive effects. Geothermal energy development can create an important shared value and positive impacts, as well as considerable negative impacts, if not properly dealt with. It is, therefore, important to identify the negative aspects that 
stakeholders are concerned by (and their nature) and determine the possible relevant solutions and mitigation strategies, to anticipate any conflict that may consequently arise.

Research around the acceptance of geothermal projects showcases its complexity. There is no unique formula but rather a broad range of different acceptance factors on different levels. For example, beyond achieving the balance between benefits for a community and the risk this community might be exposed to, acceptance is strongly linked to stakeholders' perception of the geothermal project (Figure 6) [79-83].

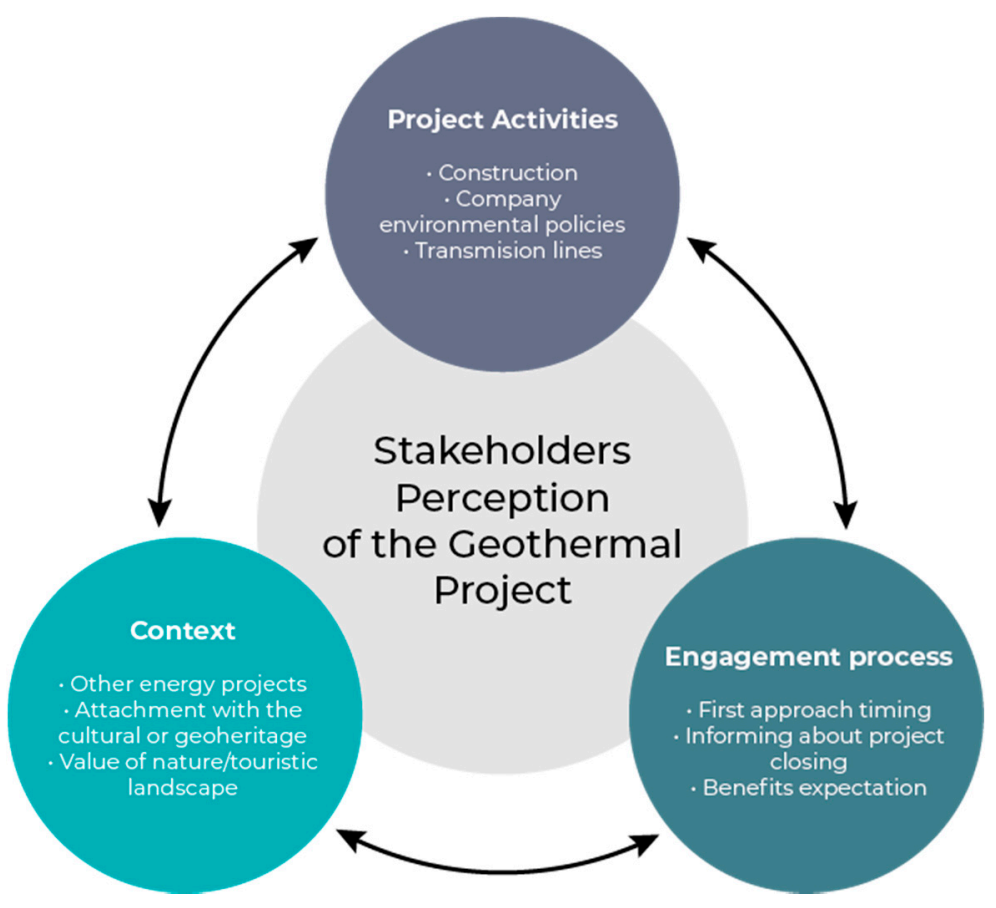

Figure 6. Influence diagram of the perception factors. The factors of each of the three categories and the combination of them influenced stakeholders' perception (modified after Vargas-Payera et al. [83].

One of the specificities of geothermal energy is that it is a domestic resource. It is developed and consumed locally, as it cannot be transported nor stored. Occurring in different levels of potential (high, medium, and low enthalpy) dependably on the geological context, geothermal energy generates, consequently, a wide spectrum of applications. This signifies that it is also directly connected to other industries and to varied types of consumers. This generates an equally wide spectrum of issues and concerns, which these groups of stakeholders will voice.

In literature, although issues and concerns are not often conceptualized, recommendations to gain and sustain an SLO include addressing the uncertainty and negative perceptions of the development of the resource, and in the case of geothermal, social acceptance requires the perception of benefits [83]. An interviewed group of geothermal representatives in Hall et al., [32] stated: "If it's not perceived as being beneficial, then I don't see how you will really get that engagement and encouragement".

\subsubsection{Creation of Mutual Benefits}

A crucial point for positive attitudes towards projects is indeed value creation and addressing the economic value of sustainability. With the promises of cleaner and renewable energy and more sustainable and climate-friendly living, comes the responsibility to bring economic value to the stakeholders, especially to the local communities [84]. This aspect can be pivotal in geothermal energy's social acceptance and a strong and sustained SLO. 


\subsubsection{Impacts: Tangible and Intangible}

Unwanted physical effects of geothermal energy development projects may have an impact on: (a) ecosystems (air, land, flora, wildlife, and surface and underground water); (b) human health and safety from water and light pollution, noise, gas emissions, and induced seismicity and (c) the economy (detrimental impact on some production activities, tourism, and damages to crops and private properties) [85]. Moreover, landscape modifications and alteration of natural features during project implementation processes often trigger an opposition from the residents, which grows as the project proceeds, especially in areas with resources suitable for geothermal-electric generation [15]. Consequently, geothermal energy is increasingly labeled by the public as costly, polluting, and dangerous for people's health.

Environmental factors can affect public acceptance of geothermal energy. Distinguishing between actual and perceived environmental risks is challenging in the communication with the public. Below is a list of geothermal energy tangible impacts and their manifestation [30].

In Europe, the share of shallow geothermal systems (mostly Ground Source Heat Pump (GSHP)) amounts to $66.5 \%$, direct use $26.2 \%$ and electricity $7.3 \%$ (installed capacity). Shallow (and low enthalpy deep) geothermal systems environmental factors include:

- Risk of groundwater contamination;

- Land subsidence and deformation;

- Visual/noise pollution;

Deep high-enthalpy geothermal systems count the following environmental factors:

- Emissions (degassing and blow-out) and non-condensable gasses (NCGs) (e.g., $\mathrm{CO}_{2}$, $\mathrm{H}_{2} \mathrm{~S}, \mathrm{NH}_{3}$ );

- Induced seismicity and land subsidence among the major negative acceptance factors;

- Visual impact and increased noise levels.

Moreover, when different energy options are available in the same area, opposition to geothermal energy projects can be instrumentalized by parties to encourage the use of energy sources other than geothermal. Indeed, geothermal energy is part of a whole new energy market related to sustainability. The development of geothermal energy projects can face fierce competition with other green/renewable energy industries, especially when the latter are much more cost-competitive and easier accessible. Therefore, on an intangible level, the context can be quite determinant, and taking into consideration potential conflicts of interest is crucial. One more factor identified through the working group exchange is the relevance of the resource utilization; indeed, the relevance of the application and the scale of the utilization of geothermal energy is an influencing factor in supporting or not a geothermal development project. According to the CROWDTHERMAL SLO working group outcomes, when geothermal energy is not redeemed relevant by the communities and stakeholders as a potential energy source, the chances to gain social approval and support are minimal.

\subsection{Conceptual Framework for SLO in Geothermal Energy}

Defining who are the stakeholders, what their concerns and challenges are, and how these can be addressed is fundamental. Through the proposed model below, we are aiming to provide a comprehensive model that integrates correlated values through social capital and engagement, SLO measurability, mitigation strategies to navigate the SLO barriers. In doing so we seek to increase understanding of the interconnected parameters influencing the SLO and to provide, thus, a more practical perspective to navigate SLO in the geothermal energy sector (Figure 7). 

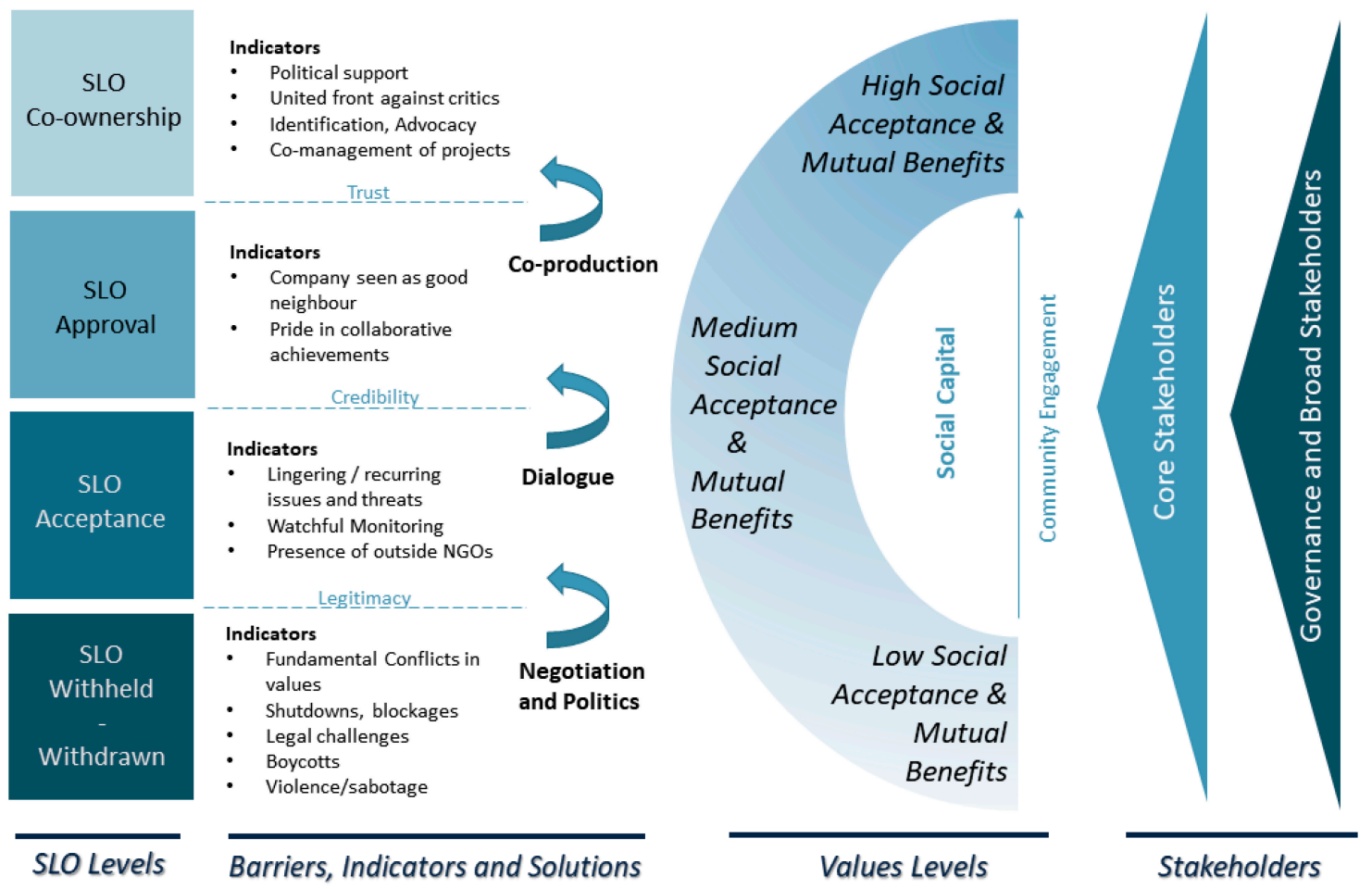

Figure 7. Conceptual Framework of SLO in Geothermal Energy.

The framework is based on the SLO pyramid model, which allows clear measurability of the SLO. Hence, our choice to integrate it in the SLO conceptual framework for geothermal energy. The components of the conceptual model are:

SLO Levels: they range between a withheld/withdrawn SLO (lowest level), to the status of acceptance (medium level), approval (high level), up to co-ownership (highest level)-also known as psychological identification. SLO levels are separated by boundaries, which are normative components of the pyramid model: legitimacy, credibility, and trust. The legitimacy boundary helps distinguish companies or projects that have lost their social license from those that maintain a minimum level of SLO. Credibility is the "quality of being believed - the capacity or power to elicit belief" and trust is "the willingness to be vulnerable to risk or loss through the action of another" [63].

Barriers, Indicators, and Solutions: they illustrate the status of the SLO at each level. Separated by the SLO normative components of legitimacy, credibility, and trust marking a separation between the SLO levels, barriers refer to the fundamental challenges faced at each SLO level and their associated symptoms. The indicators revolve around the interrelationships between the boundaries, barriers, and solutions, and are also connected to the social capital. In order to pass from one SLO level to the next, the main relevant solutions identified are (from lowest to highest levels): Negotiation and Politics, Dialogue, and Co-Production/Technical Solutions.

Values Level (Social Acceptance \& Mutual Benefits): This section represents the positive correlations between community engagement, social acceptance, and social capital, and their connection with the SLO levels. Indeed, the higher the community engagement, the higher the social capital, and, therefore, the social acceptance. Mutual Benefits are also positively correlated with social acceptance and influence consequently the social capital. Effective communication and awareness around mutual benefits increase indeed the chances to raise a higher social capital and, therefore, create more acceptance around projects developments.

Stakeholders: This part of the SLO model includes the two categories of stakeholders (core stakeholders, and governance bodies \& broader stakeholders). The core stakeholders are the local communities, local authorities (e.g., municipalities, etc.), direct users, sci- 
entists/local universities, local NGOs, and all the directly impacted stakeholders. The governance bodies and broader stakeholders are the communities and authorities at larger scales (national, regional, international), indirect users, international funding bodies, larger communities of practice/universities, NGOs.

The conceptual framework can include an additional component: Factors. These represent the other influential elements on the SLO acquisition, revision, and maintenance. They include the needs of the stakeholders, especially the local communities and the relevance of the proposed projects to those communities. Relevance of geothermal development projects is intrinsically linked to the national (and also regional and international) strategic energy utilization, and this may influence-sometimes in a domino-effect, decision-making about moving forward with a certain project or not. Another linked factor is legal and economic licenses. These can be considered both as factors and independent variables (as per the SLO Three-strand model), which are recurrent in geothermal development projects. These licenses can be indeed connected to the social license in a holistic approach-the legal license comprises all regulatory permits and statutory obligations, while the economic license comprises demands of profitability raised by investors, lenders, managers, etc. $[60,86]$. Environmental and financial risks are also factors which can arise at any stage of geothermal projects and SLO. Competition and industry perception tend to be an omnipresent challenge and factor in approving geothermal development projects. Finally, continuous dialogue is a crucial factor throughout all the processes, stages, and levels of the SLO.

\subsection{CROWDTHERMAL Case Studies: Challenges and Lessons Learned}

\subsubsection{Spain}

The Spanish Case Study is the project "Edificio Arroya Bodonal" in Tres Cantos, Madrid. It includes 80 houses powered by geothermal heat pumps and a ventilation system with integrated heat recovery, providing heating, cooling, and domestic hot water (DHC). The Arroyo Bodonal Cooperative (constituted in 2003), established the project with the aim to develop residential buildings powered by sustainable energy and operating at a high level of energy efficiency. The city of Madrid counts several similar cooperatives, which chose geothermal heating and cooling systems to ensure the supply of renewable energy and a high level of energy efficiency to the city's buildings. The project operator reported that the success of such initiative was mainly attributed to coherence between the initial plan and the implementation process, fostering, therefore, the trust element between the operator and the stakeholders.

"The commitment of the cooperative members allowed to take the project to the end without making changes on it, despite the difficulties and the attempts to modify it."

Another reported parameter highlighted by the project operator was "the importance of the figure of an expert geothermal consultant", which helped establish credibility.

"Involving an expert or consultant with deep knowledge on geothermal and the project itself as well as the minimum performance required, who is able to defend and stand for cooperative members' interests during the whole project was an indispensable part of our project implementation process."

According to the project operator, previous promoters missed a tool that guarantees confidence and credibility in the geothermal project from the project stakeholders' side (i.e., investors, financial entities, subcontracted companies). Therefore, the project followed the Trias Energetica model [87], ensuring the sustainability of the entire residential block.

"As this model was the base of the whole project, the integration of the geothermal system was immovable for cooperative members." 


\subsubsection{Hungary}

The municipally owned District Heating Company of Szeged, SZETAV, supplies heat and domestic hot water to 27,256 apartments (predominantly in 4-10 storey blocks of housing projects) and 433 public buildings (schools, kindergartens, retail units) in Sze-ged, Hungary-a city of 162,593 inhabitants near the Hungarian-Serbian-Romanian tri-border. Since 2018, SZETAV and its partners have carried out the largest geothermal district heating overhaul in Europe. When complete, the district heating in Szeged will be $60 \%$ less polluting, its energy supply will be local, and its operation will be more economical.

Within the framework of the Szeged project 1700-2000 m deep thermal wells are drilled in the Upper Town, in Odessa housing estate, in the northern part of the city, in Tarján and in Rókus, to produce $70 \mathrm{~m}^{3} / \mathrm{h}$ thermal water at $90{ }^{\circ} \mathrm{C}$. According to the plans, with the help of deep geothermal energy a total of nearly 20 million $\mathrm{m}^{3}$ of natural gas would be replaced with 600,000 GJ of geothermal energy per annum, reducing the greenhouse gas load of the city of Szeged by 35,000 tons/year, improving air quality and security of supply. The 70-million-euro development is funded from European Regional Development Fund (ERDF) sources (under the KEHOP-Környezeti és Ener-giahatékonysági Operatív Program (Environmental and Energy Efficiency Operative Programme in Hungary) scheme) and private investments.

According to the project operator, despite the remarkably low risk of the project $\left(5{ }^{\circ} \mathrm{C} / 100 \mathrm{~m}\right.$ geothermal gradient, $100 \mathrm{~mW} / \mathrm{m}^{2}$ average heat flow and a $1500 \mathrm{~m}$ thick Upper Pannonian aquifer), initial public concern was still high towards the developments and the social license to operate a challenge to obtain. The reasons for complexity in obtaining the SLO included a combination of technical, political, economic, and social factors.

“... producing thermal fluids from and injecting them into the same aquifer might be a sustainable practice, but with widely disseminated examples of failed attempts at injection into Upper Pannonian sandstone, mitigating risks is critical and both the construction and the operation of injection wells need to follow strict protocols, and have to utilize state-of-the-art know-how to be successful and to ease anxieties over such installations."

“ ... significantly increasing the production of the Hungarian-Serbian crossborder geothermal reservoir is a political and environmental issue, which needs to be addressed from the aspects of diplomatic protocol on the one hand and dynamic water-base monitoring on the other."

" ... with utility costs of private households fixed by law in Hungary, changing costs of primary energy do not affect heating bills. This results in the end-users being uninterested in switching to renewable, as high investment costs will not get balanced by lower heating bills. Thus, it becomes increasingly important to highlight the environmental advantages of geothermal."

“... drilling 9 production and injection well-triplets and laying pipelines in a densely populated city is a significant annoyance for inhabitants, and a major technological and PR challenge during planning and execution."

"This is our 6th geothermal District Heating $(\mathrm{DH})$ project in the region: what's new this time is that Szeged is by far the biggest city in the region, and interactions with the locals are frequent. In smaller towns, picking a well location away from the houses was easy-this time we are literally 40-50 m away from 4-10 storey buildings and we cause a lot of disturbance."

The project operator indicated that more time, effort, and means should have been dedicated early in the project, to involve the community in the process and, therefore, avoid complaints and resistance from the local stakeholders. 


\subsubsection{Iceland}

The Icelandic case study is a project in its early stages. The goal is to develop a concept for a community greenhouse in Húsavík, a small town in Northeastern Iceland. The project has a geothermal aspect, which is to utilize the local geothermal district heating system to heat up greenhouses to prolong the cultivation period. It also has a social aspect of engaging the community to collaborate on the project, to engage different stakeholder groups, and to foster and encourage innovation and entrepreneurship in geothermally-driven food production. The general level of acceptance for geothermal in Iceland is particularly high, the challenge is thus to maintain the interest of the relevant stakeholders in the long run. This challenge is crystallized in the following quote from one of the developers of the Icelandic case study:

"People are happy that something is happening in their society and are happy to participate in discussions on the matter. I guess, in the next phase, when we start to hammer out more precisely the project itself, it will be more difficult to keep people's engagement. We definitely learned about the importance of engaging the community. That has been our biggest focus."

\subsection{Mitigation Strategies}

\subsubsection{Co-Production and Technical Solutions}

Geothermal development is subject to the Environmental Impact Assessment (EIA) directive. A regulatory decision-making tool, the EIA framework dictates the identification and analysis of environmental stressors, and their inherent hazards and potential direct and indirect effect on population, habitats, and living organisms (GEOENVI-H2020 Project). Given the dynamic nature of geothermal projects, EIA processes are challenged to become case-dependent and adopt an approach focused on the area where the project is developed rather than the standard structural approach. This means that EIA in geothermal is processed at several stages of the project development.

The inclusion of stakeholders in this process can, therefore, become an opportunity to help leverage the SLO and reach high levels of trust, as this incites co-management and co-production processes and, therefore, strengthens co-ownership or psychological identification and pride in collective achievements among stakeholders.

\subsubsection{Intersections between SLO and Impact Assessment (IA)}

SLO is gaining more attention from IA experts. In fact, SLO is sought after by IA communities as the concept presents several interesting opportunities [88]. Indeed, whether for environmental, social, health, human rights, or other aspects to be assessed, SLO might inform or even change IA. Through the measurable indicators, SLO offers an important means of operationalizing impact prevention and mitigation, particularly in the environmental aspect. Strategic Environmental Assessments or SEAs provide an option for addressing broader regional issues that might emerge in energy development projects. SEAs can be used among other means as a mitigation tool of adverse environmental effects, a booster of transparency and credibility towards strategic level decision-making, and supporting planning and longer-term legal licensing.

\subsubsection{Dialogue and Community Engagement}

Qualitative studies in geothermal social perception show that engagement activities are essential and should be included in all stages of the geothermal project's development, thus reflecting an approach that understands and responds to the dynamics within a given region/area [83]. This approach is, therefore, case-dependent and cannot be standardized to all types of geothermal developments everywhere in the world [89]. Community engagement, thus, needs to be a continuous process throughout all geothermal project phases, including early stages [90], in order to ensure stakeholders' informative and participatory aspects. 
The analysis of the inputs from the CROWDTHERMAL SLO working group related to communication challenges and the importance of community engagement point to the necessity to address stakeholders concerns not only on a technical level but also on a sociotechnical one, which covers the interaction between people and technical aspects related to the project. Being aware of the social and cultural context, community engagement can be tackled with the aim to build trust and create more cohesive stakeholders on a social level. It would be characterized by a joint vision, shared values, intrinsic motivation, as well as transparent and trustworthy communication.

Dialogue, on the other hand, represents the "interaction interface between the project operator and the stakeholders, and it should be maintained at all stages of the project, even when SLO is at its highest and full trust achieved" [48,75,91].

\subsubsection{Negotiation and Politics}

The absence of an SLO can lead to community resistance, which can create delays, extra expenses, or reputational damage to the geothermal development projects and their operators. Failures to secure an SLO may lead stakeholders to use formal processes (e.g., environmental assessment processes) to block the granting of a legal license [50,92]. Moreover, the broader and more widespread the impacts of a project, the harder it is to be granted and then preserve an SLO. Mediation processes are, therefore, crucial in the stage where SLO is withheld or withdrawn. Negotiating with local regulators and communities of practice [38], i.e., scientists, can be determinant in establishing legitimacy and addressing the highly conflictive issues necessary in order to gain acceptance.

\section{Concluding Remarks}

The concept of the social license to operate (SLO) is context-dependent in practice and in business ethics, strongly relates to corporate social responsibility. The co-existence of businesses and people within a community relies on the development of strong relationships based on trust and mutual respect.

The general aim for a geothermal SLO, as an ethical concept, is to build bridges of trust and transparency between the geothermal industry and communities and help support the co-production process, as part of the efforts to create mutual benefits and social capital. Being a domestic resource, geothermal energy has the potential of bringing a remarkable value to the socio-economic fabric, especially in the context of the global energy transition.

From a practical perspective, the SLO is tied up with factors such as technological developments, legal licenses, economic licenses, reputational risk, financial risk, leadership, corporate social responsibility, and businesses' core values. Lack or withdrawal of SLO can put a project in jeopardy, despite the presence of a legal license and solid regulatory base. Therefore, a strong and comprehensive approach is critical to obtain and maintain an SLO. The deployment of geothermal energy is dependent on stakeholders' acceptance [93], and project shareholders are required to make geothermal development projects as participatory and transparent as possible, especially with the current energy transition framework and sustainability efforts [94]. Good quality dialogue, at all stages, is necessary to gain and maintain the SLO and anticipate conflict. Our findings show that innovative participatory financial schemes, such as the ones suggested in the CROWDTHERMAL project, can support the co-production process and ease the financial risk related to geothermal projects. Alignment of values is also fundamental, in order to build solid social capital, reach a coproduction level, and, with it, achieving trust, the ultimate boundary of the SLO. Sustained value creation and tapping into mutual benefits can take geothermal energy a long way, SLO being a thermometer of trust between geothermal operators and stakeholders. This not only applies to specific projects and initiatives, but also to the industry as a whole.

To support the institutionalization of SLO concepts into practice, some recommendations can be derived for potential actions taken on the policy level. The described conceptual approach points out the importance of SLO criteria as a principle public interest, in terms of an acceptable transformation. Thus, measures regarding the regulatory 
frame should also be used to encourage developers to invest more efforts in establishing participatory activities on the local level and reaching an SLO. Looking at other infrastructures, such as wind energy projects or transmission lines, some significant developments towards a broader and comprehensive public and stakeholder involvement can be observed over the last decade, both in planning participation and financial benefits (e.g., for the case of local municipalities, e.g., the change of the renewable energy act in Germany in 2021, regarding financial participation for residents and municipalities in wind energy projects). Learnings from these examples can be transferred and integrated into geothermal SLO procedures.

Besides the regulatory frame, softer measures can also be taken. By defining the levels of social sustainability as one criterion for public contracts or co-funding, depending on the degree of fulfilling SLO criteria, the self-commitment from developers towards SLO can be encouraged. For transparency and standardization, the achieved degree of SLO criteria can be documented by a seal or a certificate (an example is the seal fair wind project in the federal state of Thuringia, Germany). Finally, the diversity of geothermal energy applications broadens the stakeholders' spectrum, making its related SLO more complex to analyze. More research is needed to better constrain the specificities of the SLO in geothermal energy. In order to examine the possible additional or special variables involved in the social license to operate in geothermal energy, a comparison of geothermal projects in different geological/enthalpy and regional/cultural contexts, as well as different systems, is recommended.

Author Contributions: Conceptualization of the SLO model; methodology, A.B., A.W.S. and I.F.; validation, I.F. and J.H.; formal analysis, A.B.; investigation, A.B. and A.W.S.; resources, A.C.C., O.E., G.Q., T.M., I.F. and J.H.; writing—original draft preparation, A.B.; writing-review and editing, A.B., O.E., G.Q., T.M., I.F. and J.H.; project coordination, I.F.; funding acquisition, I.F. All authors have read and agreed to the published version of the manuscript.

Funding: This research was funded by EU Horizon 2020 Programme, grant number 857830 .

Institutional Review Board Statement: Not applicable.

Informed Consent Statement: Not applicable.

Data Availability Statement: Not applicable.

Acknowledgments: Thanks to Tomasz Urban for his help in redrawing and illustrating some of the figures of this paper. The present research represents the work led by the Geothermal Research Cluster (GEORG) in WP1 of the H2020 CROWDTHERMAL project (Grant Agreement n 857830).

Conflicts of Interest: The authors declare no conflict of interest. The funders had no role in the design of the study; in the collection, analyses, or interpretation of data; in the writing of the manuscript, or in the decision to publish the results.

\section{Nomenclature}

$\begin{array}{ll}\text { SLO } & \text { Social License to Operate } \\ \text { IA } & \text { Impact Assessment } \\ \text { DHC } & \text { Domestic Hot Water } \\ \text { RETs } & \text { Renewable Energy Technologies } \\ \text { NCGs } & \text { Non-Condensable Gases } \\ \text { EIA } & \text { Environmental Impact Assessment } \\ \text { NGOs } & \text { Non-Governmental Organizations } \\ \text { DH } & \text { District Heating } \\ \text { KEHOP } & \text { Environmental and Energy Efficiency Operative Programme in Hungary } \\ \text { ERDF } & \text { European Regional Development Fund } \\ \text { GSHP } & \text { Ground Source Heat Pump } \\ \text { EU } & \text { European Union } \\ \text { CCS } & \text { Carbon Capture and Storage }\end{array}$




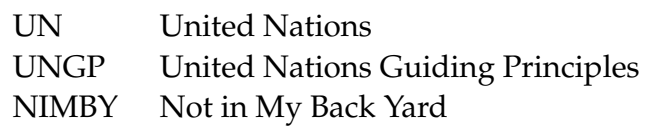

\section{References}

1. Moya, D.; Aldás, C.; Kaparaju, P. Geothermal energy: Power plant technology and direct heat applications. Renew. Sustain. Energy Rev. 2018, 94, 889-901. [CrossRef]

2. Focaccia, S.; Tinti, F.; Monti, F.; Amidei, S.; Bruno, R. Shallow geothermal energy for industrial applications: A case study. Sustain. Energy Technol. Assess. 2016, 16, 93-105. [CrossRef]

3. Palomo-Torrejón, E.; Colmenar-Santos, A.; Rosales-Asensio, E.; Mur-Pérez, F. Economic and environmental benefits of geothermal energy in industrial processes. Renew. Energ. 2021, 174, 134-146. [CrossRef]

4. Barasa Kabeyi, M.J. Geothermal Electricity Generation, Challenges, Opportunities and recommendations. IJASRE 2019, 5, 53-95. [CrossRef]

5. IEA. Technology Roadmap — Geothermal Heat and Power; International Energy Agency: Paris, France, 2011.

6. Axelsson, G. Sustainable Management of Geothermal Resources. In Proceedings of the SDG Short Course I on Sustainability and Environmental Management of Geothermal Resource Utilization and the Role of Geothermal in Combating Climate Change, UNU-GTP and LaGeo, Santa Tecla, El Salvador, 4-10 September 2016.

7. Dowd, A.M.; Boughen, N.; Ashworth, P.; Carr-Cornish, S. Geothermal technology in Australia: Investigating social acceptance. Energy Policy 2011, 39, 6301-6307. [CrossRef]

8. Ellsworth, W.L. Injection-Induced Earthquakes. Science 2003, 341, 6142. [CrossRef]

9. Giardini, D. Geothermal quake risks must be faced. Nature 2009, 462, 848-849. [CrossRef]

10. Mignan, A.; Karvounis, D.; Broccardo, M.; Wiemer, S.; Giardini, D. Including seismic risk mitigation measures into the levelized cost of electricity in enhanced geothermal systems for optimal siting. Appl. Energy 2019, 238, 850. [CrossRef]

11. Tian, T.; Huang, S. Study of environmental impact in geothermal development and utilization. In Proceedings of the 7th Asian Geothermal Symposium, Qingdao, China, 25-26 July 2006; pp. 35-44.

12. DiPippo, R. Environmental impact of geothermal power plants. In Geotherm Power Plants, 4th ed.; DiPippo, R., Ed.; Butterworth Heinemann: Oxford, UK, 2016; pp. 657-684. [CrossRef]

13. Li, Y.; Zhang, Z.; Li, Z.; Luo, Y.; Jiang, W.; Tian, Y. Measurement of subsidence in the Yangbajing geothermal fields, Tibet, from TerraSAR-X InSAR time series analysis. Int. J. Digit. Earth 2016, 9, 697-709. [CrossRef]

14. Rathnaweera, T.D.; Wu, W.; Ji, Y.; Gamage, R.P. Understanding injection-induced seismicity in enhanced geothermal systems: From the coupled thermo-hydro-mechanical-chemical process to anthropogenic earthquake prediction. Earth Sci. Rev. 2020, 205, 103182. [CrossRef]

15. Soltani, M.; Kashkooli, F.M.; Souri, M.; Rafiei, B.; Jabarifar, M.; Gharali, K.; Nathwani, J. Environmental, economic, and social impacts of geothermal energy systems. Renew. Sustain. Energy Rev. 2021, 140, 110750. [CrossRef]

16. DiPippo, R. Geothermal Power Plants: Principles, Applications, Case Studies and Environmental Impact; Butterworth-Heinemann: Oxford, UK, 2012.

17. Study on Public Perception of Geothermal Energy. Geothermal Communities Project. GeoCom-FP7 CONCERTO-239515, Deliverable 6.1. Available online: https://geothermalcommunities.eu/downloads/15 (accessed on 8 December 2021).

18. Ruef, F.; Ejderyan, O. Rowing, steering or anchoring? Public values for geothermal energy governance. Energy Policy 2021, 158, 112577. [CrossRef]

19. Poortinga, W.; Aoyagi, M.; Pidgeon, N.F. Public perceptions of climate change and energy futures before and after the Fukushima accident: A comparison between Britain and Japan. Energy Policy 2013, 62, 1204-1211. [CrossRef]

20. Bidwell, D. Thinking through participation in renewable energy decisions. Nat. Energy 2016, 1, 16051. [CrossRef]

21. Walker, C.; Stephenson, L.; Baxter, J. His main platform is 'stop the turbines': Political discourse, partisanship and local responses to wind energy in Canada. Energy Policy 2018, 123, 670-681. [CrossRef]

22. Wallquist, L.; Holenstein, M. Stakeholderanalyze Geothermie: Analyse von Einstellungen und Wahrnehmungsprozessen. Stiftung Risiko-Dialog on Behalf of Enerchange. 2012. Available online: https:/ /www.risiko-dialog.ch/wp-content/uploads/2020/03/ Geothermie_BMU_Stakeholderanalyse_SRD_20120717.pdf (accessed on 8 December 2021).

23. Benighaus, C.; Bleicher, A. Neither risky technology nor renewable electricity: Contested frames in the development of geothermal energy in Germany. Energy Res. Soc. Sci. 2019, 47, 46-55. [CrossRef]

24. Reith, S.; Kölbel, T.; Schlagermann, P.; Pellizzone, A.; Allansdottir, A. Public Acceptance of Geothermal Electricity Production; GEOELEC Deliverable No. 44; EnBW Energie Baden-Württemberg AG: Karlsruhe, Germany, 2013.

25. Vargas Payera, S. Understanding social acceptance of geothermal energy: Case study for Araucanía region, Chile. Geothermics 2018, 72, 138-144. [CrossRef]

26. Devine-Wright, P. Renewable Energy and the Public: From NIMBY to Participation; Earthscan Publications Ltd.: London, UK, 2011.

27. Devine-Wright, P. Rethinking NIMBYism: The role of place attachment and place identity in explaining place-protective action. $J$. Community Appl. Soc. Psychol. 2009, 19, 426-441. [CrossRef]

28. Cousse, J.; Trutnevyte, E.; Hahnel Ulf, J.J. Tell me how you feel about geothermal energy: Affect as a revealing factor of the role of seismic risk on public acceptance. Energy Policy 2021, 158, 112547. [CrossRef] 
29. Chavot, P.; Heimlich, C.; Masseran, A.; Serrano, Y.; Zoungrana, J.; Bodin, C. Social shaping of deep geothermal projects in Alsace: Politics, stakeholder attitudes and local democracy. Geotherm. Energy 2018, 6, 26. [CrossRef]

30. Pivot 2020-Kicking off the Geothermal Decade! Geothermal Entrepreneurship Organization (GEO). Online Event on 13-17 July 2020. Available online: https:/ / www.texasgeo.org/pivot2020 (accessed on 10 December 2021).

31. European Geothermal Council. Geothermal Decade. 2020. Available online: https://www.egec.org/geothermal-decade-2/ (accessed on 10 December 2021).

32. Hall, N.; Lacey, J.; Carr-Cornish, S.; Dowd, A.-M. Social licence to operate: Understanding how a concept has been translated into practice in energy industries. J. Clean. Prod. 2015, 86, 301-310. [CrossRef]

33. Missing Lobbyists and a Social License for Geothermal-Insights by Marit Brommer, Exec. Director, IGA. Heat Beat Blog via ThinkGeoEnergy. 2020. Available online: https:/ / www.thinkgeoenergy.com/missing-lobbyists-and-a-social-license-forgeothermal-insights-by-marit-brommer-exec-director-iga/ (accessed on 10 September 2021).

34. CROWDTHERMAL Project Consortium. Available online: https://www.crowdthermalproject.eu/ (accessed on 1 September 2019).

35. Taylor, D.F.P.; Mahlangu, S. Earning the Social Licence to Operate-A casestudy about culture. In Proceedings of the 5th International Conference on Management, Leadership and Governance, Johannesburg, South Africa, 16-17 March 2017.

36. Gunningham, N.; Kagan, R.A.; Thornton, D. Social License and Environmental Protection: Why Businesses Go Beyond Compliance. Law Soc. Inq. 2004, 29, 307-341. [CrossRef]

37. Moffat, K.; Zhang, A. The paths to social licence to operate: An integrative model explaining community acceptance of mining. Resour Policy 2014, 39, 61-70. [CrossRef]

38. Voyer, M.A.; van Leeuwen, J. Social license to operate in the Blue Economy. Resour Policy 2019, 62, 102-113. [CrossRef]

39. Smits, C.C.A.; Justinussen, J.C.S.; Bertelsend, R.G. Human capital development and a Social License to Operate: Examples from Arctic energy development in the Faroe Islands, Iceland and Greenland. Energy Res. Soc. Sci. 2016, 16, 122-131. [CrossRef]

40. Wang, S. Managing Canada's forests under a new social contract. For. Chron. 2005, 81, 486-490. [CrossRef]

41. Williams, J.; Martin, P.V. Defending the Social License of Farming: Issues, Challenges and New Directions for Agriculture; Williams, J., Martin, P.V., Eds.; CSIRO Publishing: Collingwood, Australia, 2011; p. 206.

42. Carr-Cornish, S.; Romanach, L. Exploring Community Views toward Geothermal Energy Technology in Australia; CSIRO: Pullenvale, Australia, 2012.

43. Corvellec, H. Arguing for a license to operate: The case of the Swedish wind power industry. Corp. Commun. 2007, 12, 129-144. [CrossRef]

44. Hall, N.; Ashworth, P.; Devine-Wright, P. Societal acceptance of wind farms: Analysis of four common themes across Australian case studies. Energy Policy 2013, 58, 200-208. [CrossRef]

45. Buhmann, K. Public Regulators and CSR: The 'Social Licence to Operate' in Recent United Nations Instruments on Business and Human Rights and the Juridification of CSR. J. Bus. Ethics 2015, 136, 699-714. [CrossRef]

46. Lacey, J.; Parsons, R.; Moffat, K. Exploring the Concept of a Social Licence to Operate in the Australian Minerals Industry: Results from Interviews with Industry Representatives; EP12553; CSIRO: Brisbane, Australia, 2012.

47. Thomson, I.; Boutilier, R. The social license to operate. In SME Mining Engineering Handbook, 3rd ed.; Darling, P., Ed.; Society for Mining, Metallurgy, and Exploration: Englewood, CO, USA, 2011; pp. 1779-1796.

48. Mercer-Mapstone, L.; Rifkin, W.; Moffat, K.; Louis, W. Conceptualising the role of dialogue in social licence to operate. Resour. Policy 2017, 54, 137-146. [CrossRef]

49. International Council of Mining and Metals. Council for Mining and Metals (ICMM). ICMM Position Statement on Indigenous Peoples and Mining; ICMM: London, UK, 2013.

50. Wilburn, K.; Wilburn, R. Achieving social license to operate using stakeholder theory. J. Bus. Ethics 2011, 3, 16.

51. Luning, S. Corporate Social Responsibility (CSR) for exploration: Consultants, companies and communities in processes of engagement. Resour. Policy 2012, 37, 205-211. [CrossRef]

52. Lacey, J.; Lamont, J. Using social contract to inform social licence to operate: An application in the Australian coal seam gas industry. J. Clean. Prod. 2014, 84, 831-839. [CrossRef]

53. Van Putten, I.E.; Cvitanovic, C.; Fulton, E.; Lacey, J.; Kelly, R. The emergence of social licence necessitates reforms in environmental regulation. Ecol. Soc. 2018, 3, 24. [CrossRef]

54. Edwards, P.; Fleming, A.; Lacey, J.; Lester, L.; Pinkard, E.; Ruckstuhl, K.; Bezuidenhout, C.; Payn, T.; Bayne, K.; Willimans, T. Trust, engagement, information and social licence-insights from New Zealand. Environ. Res. Lett. 2019, 14, 024010. [CrossRef]

55. Jartti, T.; Litmanen, T.; Lacey, J.; Moffat, K. National level paths to the mining industry's Social Licence to Operate (SLO) in Northern Europe: The case of Finland. Extract. Ind. Soc. 2020, 7, 97-109. [CrossRef]

56. Franks, D.M.; Cohen, T. Social licence in design: Constructive technology assessment within a mineral research and development institution. Technol. Forecast. Soc. Chang. 2012, 7, 1229-1240. [CrossRef]

57. Santiago, A.L.; Demajorovic, J.; Rossetto, D.E.; Luke, H. Understanding the fundamentals of the Social Licence to Operate: Its evolution, current state of development and future avenues for research. Resour. Policy 2021, 70, 101941. [CrossRef]

58. Yates, B.F.; Horvath, C.L. Social License to Operate: How to Get It, and How to Keep It. In Proceedings of the 2013 Pacific Energy Summit, Vancouver BC, Canada, 2-4 April 2013.

59. Asmus, P. When It Comes to Water, Can Corporations and Community Really Coexist? Available online: http://peaceandjustice. org/article.php/20090820081745528 (accessed on 19 January 2021). 
60. Gehman, J.; Lefsrud, L.; Fast, S. Social License to Operate: Legitimacy by another Name? Can. Public Adm. 2017, 60, 293-317. [CrossRef]

61. Boutilier, R.G.; Thomson, I. Modelling and Measuring the Social License to Operate: Fruits of a Dialogue between Theory and Practice. Available online: www.SocialLicence.com (accessed on 19 August 2021).

62. Joyce, S.; Thomson, I. Earning a social licence to operate: Social acceptability and resource development in Latin America. Can. Min. Metall. Bull. 2000, 93, 1037.

63. Thomson, I.; Joyce, S. The Social Licence to Operate: What It Is and Why Does It Seem So Difficult to Obtain? PDAC Convention. Available online: https://socialicense.com/publications/PDAC_2008_Social_Licence.pdf (accessed on 27 December 2020).

64. Baumber, A.; Scerri, M.; Schweinberg, S. A social licence for the sharing economy. Technol. Forecast. Soc. Chang. 2019, 146, 12-23. [CrossRef]

65. Wüstenhagen, R.; Wolsink, M.; Bürer, M.J. Social acceptance of renewable energy innovation: An introduction to the concept. Energy Policy 2007, 35, 2683-2691. [CrossRef]

66. Jijelava, D.; Vanclay, F. Legitimacy, credibility and trust as the key components of a social licence to operate: An analysis of BP's projects in Georgia. J. Clean. Prod. 2017, 140, 1077-1086. [CrossRef]

67. Parsons, R.; Moffat, K. Constructing the Meaning of Social Licence. Soc. Epistemol. 2014, 3-4, 340-363. [CrossRef]

68. Zhang, A.; Moffat, K. A balancing act: The role of benefits, impacts and confidence in governance in predicting acceptance of mining in Australia. Resour. Policy 2015, 44, 25-34. [CrossRef]

69. Zhang, A.; Moffat, K.; Lacey, J.; Wang, J.; González, R.; Uribe, K.; Cui, L.; Dai, Y. Understanding the social licence to operate of mining at the national scale: A comparative study of Australia, China and Chile. J. Clean. Prod. 2015, 108, 1063-1072. [CrossRef]

70. Gunningham, N.; Kagan, R.A.; Thornton, D. Shades of Green: Business, Regulation, and Environment. Can. J. Law Soc. 2003, 18, 153-155. [CrossRef]

71. Kagan, R.A.; Gunningham, N.; Thornton, D. Explaining Corporate Environmental Performance: How Does Regulation Matter? Law Soc. Rev. 2003, 37, 51-90. [CrossRef]

72. Thornton, D.; Kagan, R.A.; Gunningham, N. Sources of corporate environmental performance. Calif. Manag. Rev. 2003, 46, 127-141. [CrossRef]

73. Morrison, J. The Social Licence: How to Keep your Organization Legitimate; Palgrave Macmillan: Basingstoke, UK, 2014.

74. Conrad, J. The Social License to Operate and Social Contract Theory: Themes and Relations of Two Concepts-A Literature Analysis. Master's Thesis, University of Iceland, Reykjavik, Iceland, September 2018.

75. Braun, V.; Clarke, V. Thematic analysis. In Apa Handbook of Research Methods in Psychology: Research Design; Cooper, H., Ed.; American Psychological Association: Worcester, MA, USA, 2012; Volume 2, pp. 57-71.

76. Prno, J.; Slocombe, D. A systems-based conceptual framework for assessing the determinants of a social license to operate in the mining industry. Environ. Manag. 2014, 53, 672-689. [CrossRef]

77. Owen, J.R.; Kemp, D. Social licence and mining: A critical perspective. Resour. Policy 2013, 38, 29-35. [CrossRef]

78. Hilderbrand, J.; Klein, K. Stakeholder and Case Study Analysis Report. Crowdthermal Project. Deliverable 1.3. 2020. Available online: https:/ / www.crowdthermalproject.eu/wp-content/uploads/2020/11/D1.3_Stakeholder-and-case-study-analysisreport.pdf (accessed on 11 November 2020).

79. Hilderbrand, J.; Rühmland, S.; Klein, K. International Review of Public Perception Studies. Crowdthermal Project. Deliverable 1.1. 2020. Available online: https:/ / www.crowdthermalproject.eu/wp-content/uploads/2020/04/CROWDTHERMAL-D1.1 _IZES.pdf (accessed on 3 March 2021).

80. Carr-Cornish, S.; Romanach, L. Differences in public perceptions of geothermal energy technology in Australia. Energies 2014, 3, 1555-1575. [CrossRef]

81. Moser, C.; Rösch, A.; Stauffacher, M. Exploring societal preferences for energy sufficiency measures in Switzerland. Front. Energy Res. 2015, 3, 40.

82. Stauffacher, M. Risk governance for induced seismicity: A view from the social sciences. In Proceedings of the AGIS Workshop on Induced Seismicity, Schatzalp, Switzerland, 10-13 March 2015.

83. Karytsas, S.; Karytsas, C.; Mendrinos, D. Towards social acceptance of geothermal energy power plants. In Proceedings of the European Geothermal Congress, Den Haag, The Netherlands, 11-14 June 2019.

84. Vargas-Payera, S.; Martinez-Reyes, A.; Ejderyan, O. Factors and dynamics of the social perception of geothermal energy: Case study of the Tolhuaca exploration project in Chile. Geothermics 2020, 88, 101907. [CrossRef]

85. Cataldi, R. Social Acceptance: A Must to foster Geothermal Development in Next Decades. In Proceedings of the International Seminar on "The Role of Geothermal Energy in Sustainable Development of Mazowsze and Lodz Regions, Poland", Osuchòw, Poland, 4-6 October 2000.

86. Gehman, J.; Thompson, D.; Alessi, D.; Allen, D.; Goss, G. Comparative analysis of hydraulic fracturing wastewater practices in unconventional shale development: Newspaper coverage of stakeholder concerns and social license to operate. Sustainability 2016, 8, 912. [CrossRef]

87. AgentschapNL Infoblad Trias Energetica en Energieneutraal Bouwen. Zaken, A.M.v.E., Ed. 2013. Available online: http: / / www.agentschapnl.nl/content/infoblad-trias-energetica (accessed on 19 October 2021).

88. Bice, S.; Moffat, K. Social licence to operate and impact assessment. Impact Assess. Proj. Apprais. 2014, 4, 257-262. [CrossRef]

89. Trutnevyte, E.; Ejderyan, O. Managing geoenergy-induced seismicity with society. J. Risk Res. 2018, 21, 1287-1294. [CrossRef] 
90. Zhang, A.; Measham, T.G.; Moffat, K. Preconditions for social licence: The importance of information in initial engagement. J. Clean. Prod. 2018, 172, 1559-1566. [CrossRef]

91. Skoldeberg, J.; Jones, V.N.; Kupcu, M.F.; Cable, C. Changing the Game-Communications and Sustainability in the Mining Industry. Available online: https://commdev.org/publications/changing-the-game-communications-and-sustainability-inthe-mining-industry/ (accessed on 8 November 2020).

92. Wilburn, R.; Wilburn, K. Social License to Operate as a Business Strategy. Organ. Cult. Int. J. 2014, 13, 21-32. [CrossRef]

93. Karytsas, S.; Polyzou, O. Social acceptance of geothermal power plants. In Thermodynamic Analysis and Optimization of Geothermal Power Plants; Colpan, C.O., Ezan, M.A., Kizilkan, O., Eds.; Elsevier: Amsterdam, The Netherlands, 2021; pp. 65-79.

94. Davidsdottir, B. Sustainable Energy Development: The Role of Geothermal Power; Comprehensive Renewable Energy; Sayigh, A., Ed.; Elsevier: Amsterdam, The Netherlands, 2012; pp. 273-297. [CrossRef] 